Brit. J. vener. Dis. (1965), 41, 97.

\title{
HISTORY OF VENEREAL DISEASE CONTROL IN CEYLON*
}

BY

\author{
EUNICE D. C. PEREIRA AND C. S. RATNATUNGA \\ V.D. Clinic, General Hospital, Colombo, Ceylon
}

\begin{abstract}
Venereal disease in general and syphilis in particular have been mentioned in an ancient Ayurvedic medical book of Ceylon, the Särätha Sangrahàva, composed in the 5th century A.D. (De Silva, 1913). Since the diseases are mentioned it is reasonable to infer that they did in fact occur among the people of Ceylon at that time. Although detailed instructions were given regarding the diagnosis, preparation of drugs, and treatment of disease at that time, preventive measures for the benefit of the community do not appear to have been taken.
\end{abstract}

The prevalence of syphilis, however, must have declined considerably, for it appears to have been reintroduced into the island by the Portuguese at the beginning of the 16th century, an epidemic of the disease having occurred in Europe shortly before that. The disease is mentioned in Captain Joao Ribeiro's History of Ceilão which was translated into English by P. E. Pieris in 1909. Ribeiro states that: "Syphilis they [i.e., the people of Ceylon] call parangi leda, which means the Portuguese disease; and with reason, for it was we who introduced it among them." Some believe that parangi leda refers to yaws, but since Ribeiro must have been aware of the mode of transmission of syphilis it is very probable from his statement that what he refers to is, in fact, syphilis. The disease must have been quite prevalent among the Portuguese at the time. It is highly probable that yaws was introduced at about the same time by the African slaves who accompanied them.

The earliest records that we have been able to trace indicate that measures to control venereal disease in Ceylon have been in operation for only about a hundred years. Originally there were three "Lock Hospitals"- one each in Colombo, Kandy, and Galle-no doubt named after similar institutions that were already functioning in the United Kingdom. According to Lees (1961) there is some

\footnotetext{
* Received for publication August 7, 1964.
}

difference of opinion regarding the origin of the term "lock wards", some believing that they were in fact "lock-ups", while others feel that the term was derived from "les locques", these being the dressings or rags with which leprous and poxy patients covered their sores. Since the inmates of these "Lock Hospitals" were only released on the orders of a magistrate, the former view appears to be the more appropriate one for our institutions. They were probably run here with a view to controlling the incidence of venereal disease among service personnel.

The Contagious Diseases Ordinance, enacted in 1867 , sought to limit the ravages of venereal disease by the registration and periodical examination of women openly carrying on prostitution. According to the Medical Administration Report of 1878, which is the earliest record available to us, the Ordinance "had been beneficial to some extent, but was too limited in its operation to do much good".

At the beginning of the year 1878 there were 131 registered prostitutes on the list- 35 at Colombo, 28 at Kandy, and 68 at Galle. At the end of the year there were 212-96 at Colombo, 30 at Kandy, and 86 at Galle-indicating that prostitution was on the increase. Gonorrhoea, as at present, appears to have been the most prevalent venereal disease amongst those treated in the Lock wards (Table I).

TABLE I

CASES TREATED IN THE LOCK WARDS IN 1878

\begin{tabular}{|c|c|c|c|c|}
\hline Disease & Colombo & Kandy & Galle & Total \\
\hline 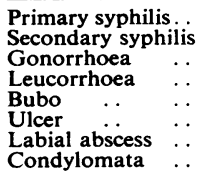 & $\begin{array}{r}43 \\
2 \\
111 \\
31 \\
5 \\
70 \\
1 \\
-\end{array}$ & $\begin{array}{r}22 \\
13 \\
53 \\
5 \\
1 \\
- \\
- \\
-\end{array}$ & $\begin{array}{r}32 \\
1 \\
131 \\
- \\
1 \\
5\end{array}$ & $\begin{array}{r}97 \\
16 \\
295 \\
36 \\
6 \\
70 \\
2 \\
5\end{array}$ \\
\hline Total .. & 263 & 94 & 170 & 527 \\
\hline
\end{tabular}


Table II shows the number of cases of venereal disease treated in the Military Hospitals of Colombo, Kandy, and Galle in the same year. Unfortunately,

TABLE II

CASES TREATED IN THE MILITARY HOSPITALS IN 1878

\begin{tabular}{|c|c|c|c|c|}
\hline Disease & Colombo & Kandy & Galle & Total \\
\hline $\begin{array}{l}\text { Primary syphilis. . } \\
\text { Gonorrhoea } \quad \ldots \\
\text { Balanitis .. }\end{array}$ & $\begin{array}{r}50 \\
30 \\
-\end{array}$ & $\begin{array}{l}10 \\
10 \\
-\end{array}$ & $\begin{array}{r}11 \\
7 \\
1\end{array}$ & $\begin{array}{r}71 \\
47 \\
1\end{array}$ \\
\hline Total .. & 80 & 20 & 19 & 119 \\
\hline
\end{tabular}

only the figures for primary syphilis and gonorrhoea are recorded, but unlike the Lock wards, syphilis appears to have been more prevalent than gonorrhoea. At this time the diagnosis of both gonorrhoea and syphilis was purely clinical and it would be difficult to assess the accuracy of these figures. One can safely surmise that the patients treated in the Lock wards were females while those attending the military hospitals were males. From the tables it does appear that early infectious syphilis was almost as frequent in the services as among the inmates of the Lock wards, while gonorrhoea was far more prevalent among the latter. This is quite contrary to the usual pattern of gonorrhoea where male cases greatly outnumber the females. Much reliance cannot, therefore, be placed on the diagnosis of gonorrhoea in the female at this time.

The working of the Contagious Diseases Ordinance during 1878 with regard to the number of cases coming under examination is shown in Table III. The Lock hospitals could not have been popular institutions, since as many as $\mathbf{8 5}$ prostitutes deserted

TABLE III

WORKING OF THE CONTAGIOUS DISEASES ORDINANCE IN 1878

\begin{tabular}{|c|c|c|c|c|}
\hline $\begin{array}{l}\text { Cases under } \\
\text { Examination }\end{array}$ & Colombo & Kandy & Galle & Total \\
\hline $\begin{array}{l}\text { No. of women on } \\
\text { list on January } 1 \\
1878 \ldots \\
\text { No. of women on } \\
\text { list on } \\
\text { December } 31 \\
1878 \ldots \\
\text { No. who deserted } \\
\text { during the year } \\
\text { Of these, no. even- } \\
\text { tually brought } \\
\text { back by the } \\
\text { police. } \\
\text { No. released by } \\
\text { order of the } \\
\text { police magistrate } \\
\text { No. of these } \\
\text { brought back for } \\
\text { examination . } \\
\text { No. of cases com- } \\
\text { ing on list during } \\
\text { the year } \\
\text { Of these, no. who } \\
\text { were volunteers }\end{array}$ & $\begin{array}{r}13 \\
-\end{array}$ & $\begin{array}{r}9 \\
-\end{array}$ & $\begin{array}{c}- \\
1 \\
- \\
18 \\
14\end{array}$ & $\begin{array}{r}22 \\
1 \\
- \\
97 \\
14\end{array}$ \\
\hline
\end{tabular}

during the year, only 22 of whom were the police able to bring back. It is obvious that prostitutes did not register themselves of their own free will and the control of venereal disease by these measures could not have been a successful procedure.

There had been an increase in the number of cases treated in these Lock and military hospitals over the years and by 1886, while the figures for the Lock hospital at Kandy had remained approximately the same, those for the hospitals in Colombo and Galle had increased considerably, primary syphilis being four times as frequent in both the latter institutions,

TABLE IV

CASES TREATED DURING 1886 AT LOCK HOSPITALS

\begin{tabular}{|c|c|c|c|c|}
\hline Disease & Colombo & Kandy & Galle & Total \\
\hline 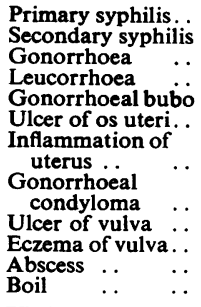 & $\begin{array}{r}164 \\
369 \\
55 \\
2 \\
53 \\
- \\
4 \\
32 \\
3 \\
-\end{array}$ & $\begin{array}{l}16 \\
8 \\
71 \\
= \\
- \\
= \\
= \\
= \\
=\end{array}$ & $\begin{array}{r}118 \\
6 \\
186 \\
2 \\
13 \\
23 \\
= \\
= \\
1\end{array}$ & $\begin{array}{r}298 \\
14 \\
626 \\
55 \\
4 \\
66 \\
23 \\
4 \\
4 \\
32 \\
3 \\
1 \\
1\end{array}$ \\
\hline Total $\ldots \quad \ldots$ & 682 & 95 & 350 & 1,127 \\
\hline
\end{tabular}

while gonorrhoea was more than three times as frequent in Colombo and one and a half times as frequent in Galle (Table IV). Likewise, the figures at the military hospitals at Colombo, Kandy, and Galle had increased, those for primary syphilis being more than twice as much as in $\mathbf{1 8 7 8}$ and those for gonorrhoea being more than thrice as much. It is interesting to note that, unlike the figures at the Lock hospital in Kandy, the figures at the military hospital in Kandy had increased considerably (Table V). It appears likely, therefore, that for some reason or other a large number of cases of venereal disease were not treated at the Lock hospital, Kandy. during that year.

The 1886 Administration Report includes for the first time a return of cases of venereal disease treated in the Government civil and district hospitals of the island (Table VI). Comparison of these figures with those for 1889, the next report available to us, shows

TABLE V

CASES TREATED DURING 1886 AT THE MILITARY HOSPITALS

\begin{tabular}{|c|c|c|c|c|}
\hline Disease & Colombo & Kandy & Galle & Total \\
\hline $\begin{array}{l}\text { Primary syphilis.. } \\
\text { Gonorrhoea } \\
\text { Balanitis .. }\end{array}$ & $\begin{array}{r}77 \\
85 \\
3\end{array}$ & $\begin{array}{r}53 \\
46 \\
3\end{array}$ & $\begin{array}{l}20 \\
49 \\
-\end{array}$ & $\begin{array}{r}150 \\
180 \\
6\end{array}$ \\
\hline Total .. & 165 & 102 & 69 & 336 \\
\hline
\end{tabular}


TABLE VI

CASES TREATED IN GOVERNMENT HOSPITALS IN 1886 AND 1889

\begin{tabular}{|c|c|c|c|c|c|c|}
\hline \multirow[t]{2}{*}{ Disease } & \multicolumn{2}{|c|}{$\begin{array}{c}\text { General } \\
\text { Hospital } \\
\text { Colombo }\end{array}$} & \multicolumn{2}{|c|}{$\begin{array}{c}\text { Other } \\
\text { Hospitals } \\
\text { in Ceylon }\end{array}$} & \multicolumn{2}{|c|}{ Total } \\
\hline & 1886 & 1889 & 1886 & 1889 & 1886 & 1889 \\
\hline $\begin{array}{l}\text { Primary syphilis } \\
\text { Secondary syphilis . } \\
\text { Tertiary syphilis } \\
\text { Congenital syphilis . } \\
\text { Gonorrhoea . } \\
\text { Bubo (gonorrhoeal). } \\
\text { Orchitis (gonorrhoeal) } \\
\text { Epididymitis }\end{array}$ & $\begin{array}{r}334 \\
125 \\
3 \\
4 \\
525 \\
24 \\
\end{array}$ & $\begin{array}{l}65 \\
59 \\
2 \\
32 \\
34 \\
\end{array}$ & $\begin{array}{r}646 \\
347 \\
1 \\
299 \\
16 \\
2\end{array}$ & $\begin{array}{r}619 \\
360 \\
2 \\
7 \\
328 \\
34 \\
7\end{array}$ & $\begin{array}{r}980 \\
472 \\
4 \\
4 \\
4 \\
824 \\
40 \\
2\end{array}$ & $\begin{array}{r}684 \\
419 \\
2 \\
9 \\
360 \\
68 \\
7\end{array}$ \\
\hline $\begin{array}{l}\text { (gonorrhoeal) } \\
\text { Arthritis }\end{array}$ & 5 & - & 8 & 1 & 13 & 1 \\
\hline $\begin{array}{l}\text { (gonorrhoeal) } \\
\text { Ophthalmia }\end{array}$ & - & 7 & 6 & 7 & 6 & 14 \\
\hline (gonorrhoeal) & 一 & 一 & 1 & - & 1 & 一 \\
\hline
\end{tabular}

a considerable reduction in early syphilis and gonorrhoea in Colombo in the latter year, while in the outstations there had been no appreciable change. It appears to us that the most reasonable explanation for this remarkable decline over such a short period, and confined to the capital city of the island, is an oversight in the recording of such cases at Colombo in 1889. Although figures for the General Hospital are recorded, a venereal disease clinic as a separate department did not function there at that time.

A lady doctor was in charge of the Lock hospital at Colombo, according to the Administration Report of 1896. It was believed that she would "be the means of inducing more of these unfortunate women to voluntarily avail themselves of the treatment so liberally provided for them by Government". Unfortunately, this hope did not materialize, the figures for 1889 showing no appreciable change from those of 1896.

In 1899 treatment for venereal disease was provided at the Lock hospitals in Colombo, Kandy, and Galle as well as in $\mathbf{2 5}$ other institutions in various parts of the island. Four stations were recorded as appearing "to have enjoyed immunity", no cases having been reported from these institutions.

The next report available to us is that of 1908; it is very brief and states that at the branch or Lock hospitals at Colombo and Galle 13 cases of primary, 163 of secondary, and 111 of tertiary syphilis, as well as 250 cases of gonorrhoea were treated. According to these figures there appears to have been a marked reduction of primary syphilis and gonorrhoea from 1886, and a correspondingly marked increase of secondary and tertiary syphilis. The diagnosis of syphilis here at this time was still clinical and the high proportion of tertiary syphilis raises doubts in one's mind as to how correct such a diagnosis was.

It is clear from the foregoing that the Government was alive to the problem of venereal disease and provided free treatment for such diseases at several institutions in various parts of the island. One must conclude, however, that during these years the control of venereal disease was very unsatisfactory, as no contact investigation, case-holding, or public education procedures had been undertaken. Further, no provision appears to have been made even for the treatment of civilian males until 1886.

It is unfortunate that records of the activities in this field during the years 1909 to 1920 are not available. We are thus not in a position to describe the situation that prevailed during this period.

\section{Venereal Disease Commission}

Venereal disease control on an organized basis was started in Ceylon in August, 1921, following the recommendations of a Venereal Disease Commission appointed by $\mathrm{Mr}$ (later Sir) Winston Churchill, which had arrived in the island in May, 1920. After touring the country and meeting various sections of the people, a Ceylon National Council was established for combating venereal disease, affiliated to its counterpart in England. The National Council requested the Government to take action upon the lines indicated by the Commission, which were as follows:

(1) That facilities for treatment of venereal disease should be made available to all people.

(2) That propaganda, having for its object public enlightenment on the great amount of damage done to the community, should be undertaken.

(3) That, after facilities had been provided for treatment and the public had become acquainted with the danger of these diseases, the Government should be requested to make notification compulsory.

As a result of the visit of the Commission and the efforts of the National Council on venereal disease certain facilities were established:

(1) A clinic was opened in the port of Colombo in 1921 for the treatment of seamen.

(2) A clinic was established at the Branch (Lock) Hospital, Colombo, for the treatment of women and children on two afternoons a week.

(3) A clinic was established at the out-patients' department, General Hospital, Colombo, for the treatment of males on two afternoons a week.

(4) Neo-salvarsan was made available to all Government hospitals in the island.

Although free treatment was offered to all it was generally accepted by only the lower socio-economic group. Those of the higher income groups sought private treatment, no doubt on account of the social stigma attached to these diseases. 
Table VII shows the cases treated at the Venereal Disease Clinic, General Hospital, Colombo, in 1922. These figures indicate a position nearer that of 1886 than 1889 , confirming our doubts as to the accuracy of the 1889 figures. Chancroid has been included in the return for the first time, and primary and secondary syphilis seem to have changed places as regards frequency. Tertiary syphilis has obviously increased, probably due to better recording.

TABLE VII

CASES TREATED AT THE VD CLINIC, GENERAL HOSPITAL, COLOMBO, IN 1922

\begin{tabular}{|c|c|c|c|c|c|c|}
\hline \multicolumn{6}{|c|}{ Disease } & No. \\
\hline $\begin{array}{l}\text { Primary syphilis } \\
\text { Secondary syphilis } \\
\text { Tertiary syphilis } \\
\text { Chancroid } \\
\text { Gonorrhoea } \\
\text { Yaws . . . } \\
\text { Ya }\end{array}$ & $\begin{array}{l}\ldots \\
\cdots \\
\cdots \\
\cdots \\
\cdots\end{array}$ & $\begin{array}{l}\cdots \\
\cdots \\
\cdots \\
\cdots \\
\cdots\end{array}$ & $\begin{array}{l}\cdots \\
\cdots \\
\cdots \\
\cdots \\
\cdots\end{array}$ & $\begin{array}{l}\cdots \\
\cdots \\
\cdots \\
\cdots \\
\cdots\end{array}$ & $\begin{array}{l}\cdots \\
\cdots \\
\cdots \\
\cdots \\
\cdots\end{array}$ & $\begin{array}{r}109 \\
369 \\
34 \\
182 \\
318 \\
92\end{array}$ \\
\hline
\end{tabular}

In the 1922 Administration Report, the work done is recorded as being "thoroughly up to date, microscopic and serological tests are done as a routine, and careful records kept of all cases; printed forms explaining the nature of gonorrhoea and syphilis are distributed to the patients". A further step forward had thus been taken in venereal disease control in that patient education was introduced at the Venereal Disease Clinic, Colombo. It is unfortunate to note, however, in the Report for 1925 that "diagnosis of cases of syphilis is mainly made by the clinical characters but when in doubt the Wassermann test is being made use of or smears for the spirochaete are examined under the microscope". Even more unfortunate is the fact that this reliance on clinical diagnosis still prevails in many institutions up to the present day.

It is interesting to read in the same report that "syphilis in this country does not seem to affect the central nervous system as frequently as it does in European countries, so that it is rare to see specific disease of the brain and spinal cord in Ceylon, and diseases like general paralysis of the insane and tabes dorsalis are seldom met with". However, no statistics are recorded to support this statement and as surgeons were in charge of the Venereal Disease Clinic at the General Hospital, Colombo, up to the early 1950 s, one wonders whether such infrequency cannot be accounted for by the fact that patients with syphilis of the nervous and cardiovascular systems were seen by physicians and, as medical cases, were treated by them without reference to the venereal disease clinic.

The same report also records that at the Port Venereal Disease Clinic for seamen, 56 cases of syphilis were treated in 1925 as compared with 61 in
1924 and 68 in 1923. These were generally infections that had been acquired in neighbouring countries. Since a clinic was already functioning at the port of Colombo, it was possible for Ceylon to undertake to adhere to the International Venereal Diseases Agreement of Brussels in 1928.

The venereal disease clinics at the General Hospital and the Branch Hospital, Colombo, had been functioning on two afternoons a week since their inception in 1921. However, by 1934 the clinic at the General Hospital, Colombo, was functioning daily in the afternoons except on Sundays.

It was soon realized that the venereal disease service should be extended to the outstations, and in October, 1931, a venereal disease clinic was opened in the Kandy Dispensary. The clinic was conducted on two evenings a week, and a statement of cases treated there in 1932 is shown in Table VIII. According to these figures, both gonorrhoea and syphilis were quite prevalent in Kandy at that time. No mention, however, is made of the frequency of the various stages of syphilis.

\section{TABLE VIII}

CASES TREATED AT THE VD CLINIC, KANDY, IN 1932

\begin{tabular}{|c|c|c|c|c|c|c|}
\hline \multicolumn{6}{|c|}{ Disease } & \multirow{2}{*}{$\begin{array}{r}\text { No. } \\
161 \\
289 \\
23 \\
26 \\
52\end{array}$} \\
\hline $\begin{array}{l}\text { Syphilis . . } \\
\text { Gonorrhoea } \\
\text { Gonorrhoea and } \\
\text { Yaws ... } \\
\text { Skin diseases }\end{array}$ & $\begin{array}{cc}\ldots & \ldots \\
\text { d } & \text { syphilis } \\
\ldots & \ldots \\
\ldots & \ldots\end{array}$ & $\begin{array}{l}\ldots \\
\cdots \\
\cdots \\
\cdots \\
\cdots\end{array}$ & $\begin{array}{l}\cdots \\
\cdots \\
\cdots \\
\cdots\end{array}$ & $\begin{array}{l}\cdots \\
\cdots \\
\cdots \\
\cdots\end{array}$ & $\begin{array}{l}\cdots \\
\cdots \\
\cdots \\
\cdots\end{array}$ & \\
\hline Total .. & $\ldots$ & $\ldots$ & .. & $\ldots$ & $\ldots$ & 551 \\
\hline
\end{tabular}

New Scheme.-Further improvement in venereal disease control work was achieved when a new scheme, formulated in 1936, was put into effect in 1938. It included:

(1) Training of an officer in curative and sociological work.

(2) Bringing all sections of the curative organization as regards venereal disease work under one control.

(3) Establishing clinics in the outstation hospitals and dispensaries, training of personnel, and providing adequate accommodation and staff.

(4) Organizing publicity on proper lines.

In 1937 a further clinic was opened at the Galle Dispensary, held every Saturday. During the year 549 cases of syphilis were treated in the clinic, but as at Kandy, the various stages are not mentioned. Further, no record has been made of the other venereal diseases treated there. 


\section{Venereal Disease Ordinance}

The Venereal Disease Ordinance (Cap. 224) was enacted in 1938. It provided for the treatment of venereal disease by no person other than: (a) a registered medical practitioner; or (b) a practitioner of indigenous medicine who has been specially thereto authorized in writing by the Governor with the advice of the Executive Committee.

However, the Ordinance was not enforced as the "proper authority" for the various areas were not declared and in practice venereal diseases were treated, and still continue to be treated, by unauthorized persons. The situation that results from such uncontrolled treatment is not as bad as one would imagine it to be, for, as Laird (1959) points out, the rather excessive dosage of penicillin usually given for urethritis by these persons contributes to the control of infectious syphilis and is perhaps beneficial to the community at large.

In 1942 the Venereal Diseases Regulations were introduced, making it incumbent on doctors to report cases of gonorrhoea in the female and requiring infected females to submit to full treatment. In the following year the Venereal Disease regulations were amended to apply to males as well, and syphilis and chancroid were included as well as gonorrhoea. These regulations were gazetted on October 15, 1943, but again were not enforced because: (a) it was felt that persuasion was better than compulsion; (b) there was a reluctance on the part of doctors to notify cases even though not by name; (c) there was lack of staff; (d) specific areas were not declared.

Since the laws so far enacted were ineffective, further legal measures were introduced on November 1,1954 , when venereal diseases were made notifiable in Colombo. No case, however, has yet been notified to the central authority! Our venereal disease control programme, therefore, though Scandinavian on paper, follows largely the British method in practice.

\section{Further Progress}

Further steps in venereal disease control were taken in 1939. In that year the late $\mathrm{Dr}$ H. C. P. Gunewardene, who was specially trained in venereal disease at the Whitechapel Clinic, London, and at other clinics in England and Europe, returned to the island and was appointed Surgeon-in-Charge, Genito-urinary Clinic, Colombo, this being the new designation given to the Venereal Disease Clinic. This department then made available to all practitioners, entirely free of charge, all laboratory tests for the diagnosis of venereal disease. The service was introduced to encourage private practitioners to confirm the diagnosis prior to prescribing treatment.
Few practitioners, however, availed themselves of this opportunity.

The venereal disease clinics at the General Hospital and the Branch Hospital were reorganized by the late $\mathrm{Dr}$ Gunewardene, ably assisted by $\mathrm{Dr}$ C. J. L. Misso. Cards and forms for the proper recording and follow-up of cases were printed. Accurate records of patients' names and addresses, clinic and laboratory findings were maintained in a confidential manner, patients being known by numbers thereafter. Pamphlets and leaflets in English, Sinhala, and Tamil were also printed and made available to patients. Three films on gonorrhoea and syphilis were purchased and shown to the public in Colombo and the provinces.

Too much credit cannot be given to the late $\mathrm{Dr}$ H. C. P. Gunewardene, for it was to his zeal and enthusiasm that we owe the basic structure of our venereal disease services. The subsequent breakdown of these services was through no fault of his, but due to other and more pressing demands on the Health Department immediately following the cessation of hostilities of the Second World War.

In 1941 two visiting clinics were opened, one in the Coal Grounds, Port of Colombo, for dock workers, and the other in the Vagrants' Home, Angoda, where vagrants of the City of Colombo were detained on the orders of the magistrate. The home was run by the Salvation Army who afforded all facilities for treatment of the inmates. It was visited twice a week by a medical officer from the Central Venereal Disease Clinic, Colombo; all persons admitted to the home were examined for venereal disease and treated if necessary. These patients were released after treatment only when certified as non-infectious by the medical officer. Since 1951 these visits have been stopped, but the vagrants are brought regularly to the Central Venereal Disease Clinic, Colombo, for examination and treatment.

The clinic in the Coal Grounds was also visited twice a week by a team from the Central Venereal Disease Clinic, Colombo. It functioned for the convenience of the dock workers. Facilities for darkfield and bright-field examinations were available and samples of blood were taken to the Central Clinic for examination. However, this clinic, too, ceased to function within a few years and the dockworkers were forced to revert to the old practice of visiting the Central Clinic, Colombo, situated about four miles away.

Outside Colombo regular venereal disease clinics were being conducted only at Kandy and Galle. It was considered essential that the venereal disease services should be extended to the other outstations to provide for coverage of the whole island. Such an 
extension could only be effective if those engaged in the control of venereal disease were adequately trained. Medical officers in charge of these clinics needed to be conversant with the correct methods of diagnosis, treatment, and follow-up, and the proper maintenance of records, as well as publicity measures. Further, this training had to be a continuous process to ensure the appointment of trained officers to man the various clinics throughout the island. With this end in view the training of medical officers was started in 1941, 10 officers being trained in that year -4 for a period of three months, 2 for one month, and 4 for two weeks - and venereal disease clinics were opened in several of the bigger outstation hospitals.

At a conference held on December 24, 1943, at the office of the Director of Medical and Sanitary Services, it was decided to open 10 clinics in 1944, and to carry out more propaganda work, in addition to the distribution of pamphlets and to the talks and cinema demonstrations which were already being given. As it was difficult to get the newspapers to publish advertisements on venereal disease it was resolved to have them published in weekly and monthly magazines in the national languages.

By the end of 1944 there were 23 part-time clinics in the island, of which 13 were under specially trained medical officers. During the year another 4 medical officers were trained. More propaganda work was also done. It was noted that the work in the island was steadily increasing in volume, partly due to the propaganda work undertaken by the department and partly to an actual increase in the incidence of these diseases (Table IX).

TABLE IX

ATTENDANCE AT VD CLINICS IN CEYLON

\begin{tabular}{c|c|c|c}
\hline Year & First Visits & $\begin{array}{c}\text { Subsequent } \\
\text { Visits }\end{array}$ & Total Visits \\
\hline 1942 & 11,502 & 55,345 & 66,847 \\
1943 & 16,516 & 84,899 & 101,415 \\
1944 & 17,800 & 89,811 & 107,611 \\
1945 & 15,515 & 83,990 & 99,505 \\
1946 & 13,806 & 87,222 & 101,028 \\
1947 & 10,513 & 98,548 & 109,061 \\
1948 & 11,907 & 107,243 & 119,150 \\
\hline
\end{tabular}

With a view to making treatment available in all parts of the island, new clinics were established in the provincial and district hospitals, some dispensaries, and health centres. New buildings were put up where necessary to provide accommodation for the treatment of venereal disease and adequate laboratory facilities were also provided.

A Ceylon Society for Moral and Social Hygiene was formed in 1944 to assist in the after-care and rehabilitation of venereal disease patients. Organized as a private enterprise, it was anxious to establish friendly contact with the men and women attending the venereal disease clinics to see what assistance could be given to them by way of encouraging them to continue treatment until they were cured. It was also intended to help the women, in particular, to find suitable employment and new ways of life. Laudable though its intentions were, it is sad to record that the society wound up in a very short space of time, not having achieved any of its objectives.

By 1948, although 37 medical officers had been trained in venereal disease (6 fully and 31 partly) it was regrettable to note that only one outstation clinic was manned by a fully trained officer. This was the result of a failure to replace trained personnel by similarly trained officers when the former, for various reasons, were transferred to other work.

\section{Contact Investigation and Case-holding}

Case-holding was introduced to the Colombo Clinics in 1941 and contact investigation a couple of years later. There is no doubt that they are the basic requirements for any venereal disease control programme. Being so delicate a matter and one where the difficulties encountered were so many, contact investigation had been confined at first to the investigation of marital partners only. Later, however, this activity was extended to include all relevant sex contacts.

TABLE $X$

COMPARISON OF FIRST AND SUBSEQUENT VISITS AT THE COLOMBO, BRANCH, AND OUTSTATION VD CLINICS

\begin{tabular}{|c|c|c|c|}
\hline Year & $\begin{array}{l}\text { Colombo } \\
\text { VD Clinic }\end{array}$ & $\begin{array}{l}\text { Colombo } \\
\text { Branch } \\
\text { (Female) } \\
\text { VD Clinic }\end{array}$ & $\begin{array}{l}\text { Outstation } \\
\text { VD Clinics }\end{array}$ \\
\hline $\begin{array}{l}1942 \\
\text { First visits } \\
\text { Subsequent } \\
\text { visits } \\
\text { Ratio of sub- } \\
\text { sequent to } \\
\text { first visits .. }\end{array}$ & $\begin{array}{r}3,340 \\
24,787 \\
7 \cdot 4\end{array}$ & $\begin{array}{r}2,388 \\
9,278 \\
3 \cdot 9 \\
\end{array}$ & $\begin{array}{r}5,774 \\
21,280 \\
\\
3 \cdot 7\end{array}$ \\
\hline $\begin{array}{l}1948 \\
\text { First visits } \\
\text { Subsequent } \\
\text { visits } \\
\text { Ratio of sub- } \\
\text { sequent to } \\
\text { first visits .. }\end{array}$ & $\begin{array}{r}3,086 \\
51,701 \\
16 \cdot 8\end{array}$ & $\begin{array}{r}2,072 \\
12,608 \\
6 \cdot 1\end{array}$ & $\begin{array}{r}6,749 \\
42,934 \\
6 \cdot 4\end{array}$ \\
\hline
\end{tabular}

The success of follow-up work is shown in Table $\mathrm{X}$ where subsequent visits are shown to have almost been doubled between the years 1942 and 1948. The follow-up was found to be best at the Male Venereal Disease Clinic, Colombo. These were the days when treatment was by arsenic and bismuth and caseholding was even more important a procedure then than it is at present. 
The results of contact investigation show a gradual improvement over the years 1945 to 1949 (Table XI). Greater success appears to have been achieved with family contacts in that a higher percentage of positive cases have been detected. These mainly refer to family contacts of late syphilitics and since the children, too, are examined a higher percentage of positives must necessarily obtain than if the marital

TABLE XI

RESULTS OF CONTACT INVESTIGATION 1945-49

\begin{tabular}{|c|c|c|c|c|c|c|}
\hline \multicolumn{2}{|l|}{ Contacts } & 1945 & 1946 & 1947 & 1948 & 1949 \\
\hline \multicolumn{2}{|c|}{ 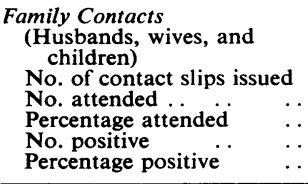 } & $\begin{array}{r}566 \\
213 \\
38 \\
92 \\
43\end{array}$ & $\begin{array}{r}657 \\
319 \\
49 \\
152 \\
48\end{array}$ & $\begin{array}{r}719 \\
390 \\
54 \\
211 \\
54\end{array}$ & $\begin{array}{r}858 \\
433 \\
50 \\
210 \\
49\end{array}$ & $\begin{array}{r}912 \\
465 \\
51 \\
249 \\
55\end{array}$ \\
\hline $\begin{array}{l}\text { Extra-marital Contacts } \\
\text { Total examined } \\
\text { No. positive } \\
\text { Percentage positive }\end{array}$ & $\begin{array}{l}\ldots \\
\ldots\end{array}$ & $\begin{array}{r}501 \\
63 \\
12.6\end{array}$ & $\begin{array}{r}544 \\
66 \\
12\end{array}$ & $\begin{array}{r}767 \\
113 \\
14 \cdot 7\end{array}$ & $\begin{array}{r}1,052 \\
148 \\
14\end{array}$ & $\begin{array}{r}1,112 \\
206 \\
18 \cdot 5\end{array}$ \\
\hline
\end{tabular}

partners only were examined. From a public health point of view, however, extra-marital contacts, being generally infectious cases, are far more important. A more accurate picture would have been obtained had the diseases been separated and the diagnoses of patients and contacts split up into infective and noninfective stages. The low percentage of extra-marital contacts found positive (the highest being only $18 \cdot 5$ per cent. in 1949) indicates how difficult this procedure is in a country with low educational standards. Contacts cannot be made to understand that one examination is inadequate and that repeated check-ups are necessary.

\section{WHO Assistance}

In 1949 a fresh impetus was given to venereal disease control work by the arrival of Dr George Leiby, Professor of Syphilology of the University of California. This visit was the result of a request made to the World Health Organization by the Government of Ceylon. According to the 1949 Administration Report, he was quite impressed by the work done in the island and considered the venereal disease control programme as carried out at that time very satisfactory, the only drawback being the lack of an adequate number of trained personnel and the frequent transfer of those who had specialized in this field of work. Perhaps his remarks were confined to a comparison with other countries in South-east Asia. He was particularly impressed by the contact investigation work done in Colombo. As a result of his visit it was proposed to organize venereal disease work on a five-year plan with the object of having 60 venereal disease clinics in the island at the rate of 12 per year, each in the charge of a specially trained venereal disease officer who would devote his whole time to this work. He would also have a specially trained public health inspector, a nurse, and a laboratory assistant, all of whom would be full-time officers, to help him. It took another two years, however, before Professor Leiby's recommendations* were put into effect.

\section{Therapy}

The sulphonamides were introduced for the treatment of gonorrhoea in Ceylon in 1937 and were found to be very effective. Within a few years, however, they became almost totally ineffective. It was only in 1946 that we were able to obtain penicillin for the treatment of this disease. Even though given in the low dosage of 50,000 units crystalline penicillin twice a day for one day (together with a course of sulphonamide), the disease responded dramatically. As penicillin became more freely available the dosage was increased, and later, in 1951 , crystalline penicillin was replaced by procaine penicillin with aluminium monostearate (PAM). In recent years the oral antibiotics have also been made available to us for the treatment of problem cases. Although allergic reactions do occur with penicillin, they have not so far been a troublesome feature.

In 1950 the old pattern of treatment of syphilis was changed. Arsenic and bismuth, which had been used since the early 1920 s, gave way to procaine penicillin with aluminium monostearate. The result was that a larger proportion of patients-29.4 per cent. during the year under review-received a complete course of treatment as compared to about 10 per cent. with the old form of treatment. The "complete course", however, was only 300,000 units of PAM in most instances, and 300,000 units daily for 3 days in the rest! Where supplies of PAM were not available, crystalline penicillin was administered 4-hourly round the clock for 8 to 15 days, depending on the stage of the disease. Unfortunately when the clinic moved to its new premises in 1952 , most of the old files, including those of patients who had been given a single injection of 300,000 units of PAM for early syphilis, were destroyed. An attempt is now being made to review as many as possible of the records that escaped destruction.

* Report on the Control of Venereal Disease in Ceylon, submitted to the Director of Medical and Sanitary Services, Ceylon, by Prof. to the Director of Medical and Sanitary Services, Ceylon, by Prof. Leiby in 1949. Copies available in the files of the Superintendent,
Anti-VD Campaign, Colombo, WHO Regional Office (New Delhi), Anti-VD Campaign, Colombo, WH
and WHO Headquarters (Geneva). 


\section{Preventive Measures Improved}

In 1950 contact investigation procedures were intensified and were under the care of the Supervising Public Health Inspector, $\mathrm{Mr}$ D. T. S. S. Gunewardene, who had then returned from the United States after special training in this type of work. Health education work, too, was intensified. The need to educate the public about syphilis and gonorrhoea was emphasized and became a daily routine activity at the clinics in Colombo. Patients were instructed in the nature of their particular disease, the mode of transmission, the importance of regular attendance, the value of full treatment and follow-up, as well as the necessity for referring contacts to the clinic.

Mass education, too, was undertaken on a bigger scale. Attempts were made to make people realize, regardless of moral implications, that syphilis and gonorrhoea were preventable diseases, and that for those who had contracted them quick and effective remedial measures were now available. Syphilis and gonorrhoea were again referred to by name instead of the polite phrase "social diseases".

It was rightly observed that unsuitable living conditions, low wages, poor homes, and lack of sanitary facilities ranked high as indirect causes of venereal diseases. Not only did these diseases thrive among the poor and unfortunate but so did other social evils. It was urged that slum clearance, the building of sanitary dwelling houses, and the provision of recreational facilities should be vigorously tackled. These were, however, big problems which required Government intervention and could not be dealt with by the Health Department alone. Although efforts to improve living conditions have been made by the Government, they are of no avail, because of a rapidly increasing population and the limitation of funds.

\section{WHO Venereal Disease Control Team}

In February, 1951, Dr T. Guthe, Chief of the Venereal Disease Section, WHO, Geneva, and Dr N. Jungalwallah, Regional Adviser in Venereal Diseases, WHO Regional Office for South-east Asia, visited the island. As a result of their recommendations and following the discussions they had with the Government of Ceylon, the World Health Organization established the Venereal Disease Control Project (Ceylon 5), and a team under the leadership of $\mathrm{Dr}$ S. M. Laird arrived in the island in July, 1951. He reorganized the venereal disease services and through his good offices the Anti-Venereal Disease Campaign was set up in 1952 .
The objectives of the project (Laird, 1952) were to:

(1) Establish a model venereal disease clinic in Colombo which would serve as (a) the chief clinic of Ceylon, and (b) the training centre for medical and para-medical staff.

(2) Develop a full venereal disease service with trained staff in the major outstations.

(3) Establish serological testing of expectant mothers as a routine and thus control congenital syphilis.

(4) Train local staff in simple serological testing so as to provide such facilities in the main outstations.

(5) Develop the diagnostic and treatment facilities for seafarers in the Port of Colombo.

The results achieved by the Venereal Disease Control Team in the first year were as follows:

(a) The model clinic was completed and came into operation in March, 1952.

(b) The first batch of medical officers was trained between June and August, 1952. A second batch began training on September 15, 1952.

(c) Serological testing of expectant mothers was started as a routine in April, 1952, at the Antenatal Clinic, Castle Street Maternity Home, Colombo. This routine testing was conducted by the WHO nurse. In July, 1952, the service was extended to the six municipal antenatal clinics in Colombo.

(d) The scheme to train local technicians to undertake simple serological tests at outstations broke down as no suitable candidates could be found. As a result, the WHO serologist was recalled and the serological equipment was transferred elsewhere.

With the development of the model clinic in Colombo, a campaign of public education in venereal disease was developed. The press and Radio Ceylon assisted in that campaign. Regular lecturedemonstrations on venereal diseases were given to undergraduates and postgraduates as well as to paramedical personnel and these are being continued all through the year. Lecture-demonstrations were also included in the courses of instruction arranged for village leadership.

During 1953 the activities of the campaign were expanded and it was possible to develop seven venereal disease clinics with trained staff on a fulltime basis at the bigger outstations. The Superintendent was made responsible in 1953 for the eradication of yaws from the island. Yaws had by that time receded considerably, and it is now no longer a problem here (Pereira, 1962). A further two clinics were established in 1954. By 1960 there were nine full-time venereal disease clinics in the 
outstations-Jaffna, Katugastota (Kandy), Galle, Kurunegala, Ratnapura, Badulla, Anuradhapura, Negombo, and Horana. Eight peripheral clinics, each situated some miles away from the respective central station, are also conducted by the personnel of the corresponding full-time venereal disease clinic.

\section{Prevention}

Routine Ante-natal Serological Test for Syphilis and the Prevention of Congenital Syphilis.-This activity, which was started in Colombo in 1951, has been maintained. The reactive cases and their family contacts are investigated and treated at the Central Venereal Disease Clinic, Colombo. At outstations, routine antenatal blood tests have been established where full-time venereal disease clinics function. All public health nurses have been instructed to establish routine blood testing at antenatal clinics wherever this procedure has not yet been started.

There are certain difficulties at present which hinder the expansion of this activity. Whether these can be overcome will depend essentially on the extension of the full-time outstation venereal disease clinics, on increased laboratory facilities, and on the assistance and co-operation of the obstetricians. public health nurses, and midwives.

Serological Test for Syphilis (STS). - The original scheme for establishing a serological laboratory by the WHO Venereal Disease Team was abandoned in December, 1951, as the Government of Ceylon could neither provide the accommodation for this laboratory nor the personnel for training. The Medical Research Institute, Colombo, continued to do the serological tests for syphilis for all institutions in the island.

The disadvantages of centralizing all serological tests for syphilis at the Medical Research Institute were pointed out by Dr Mackenzie Pollock, WHO Regional Adviser on Venereal Disease and Treponematoses, New Delhi, who visited Ceylon in May, 1953*. Following a conference held at the office of the Director of Health Services on March 24, 1954, a scheme was formulated for including venereal disease serology within the Anti-Venereal Disease Campaign. The first stage of the scheme was implemented in May, 1956, when the VDRL slide test was introduced to the Central Venereal Diseases Clinic, Colombo. Two years later, in June, 1958, this test was established at the clinic in Jaffna and on

\footnotetext{
* Report by the Regional Adviser on Venereal Disease and Treponematoses, New Delhi, available in the files of the Superintendent, Anti-Venereal Disease Campaign.
}

January 1, 1959, at Katugastota and Ratnapura. By January, 1962, the test was being done in another two laboratories, at Badulla and Galle.

The Department of Health Services has, however, recently revised its original decision and ordered the amalgamation of the venereal disease clinic laboratory work with that of the provincial laboratories supervised by pathologists-Jaffna, Galle, Ratnapura, Badulla, Kurunegala, and Anuradhapura. The new arrangement, though administratively convenient, has certain drawbacks in that the medical officer of the venereal disease clinic has no supervision over venereal disease serology, while the pathologist may not find sufficient time to devote to this subject amidst all his other duties.

Port Venereal Disease Project.-The development of a port demonstration project in Colombo had been studied by the Senior Adviser, WHO Venereal Disease Control Team, and he felt that this project, as defined in the plan of operations, was unlikely to succeed. He put forward alternative proposals and recommended that adequate clinic premises should be provided near the port passenger terminal. He further suggested that the port clinic should be closely integrated with the Colombo Venereal Disease Service and that it should also be open to labourers working in the port of Colombo.

On October 14, 1958, the Port Venereal Disease Clinic, sited opposite the main gate of the passenger terminal, was opened. It is conducted daily by staff from the Central Venereal Disease Clinic, Colombo, from 2 p.m. to 4 p.m., and is open to seafarers as well as to persons working within close proximity to the port of Colombo. Seafarers are also now offered free attention by trained personnel at the other two ports of Ceylon, Galle and Trincomalee. With the establishment of the Port Venereal Disease Clinic, the fifth and final chief objective of the WHO Venereal Disease Project had been achieved.

The work of the Anti-Venereal Disease Campaign, which since 1953 had been conducted entirely by the national staff, progressed so satisfactorily that by 1958, when Dr Laird revisited the island as a shortterm WHO venereal disease consultant, he was able to observe "that the AVD Campaign has made solid progress and that the initial improvement stimulated by the WHO team during 1951-53 has been extended by the national staff during the past five years". (Laird, 1959.)

\section{Summary}

Venereal diseases occurred in Ceylon as early as the 5th century, A.D. The earliest measures to control them, however, appear to have been taken as 
recently as nearly a hundred years ago. Control measures on an organized basis were introduced in 1921 and they have been improved over the years.

The basic structure of the venereal disease services in Ceylon was the result of the efforts of the late Dr H. C. P. Gunewardene when he returned to the island in 1939 after undergoing training abroad. Owing to lack of personnel these services almost completely broke down by about 1951 .

Between 1949 and 1953 the World Health Organization gave considerable assistance, advice, and encouragement towards re-establishing an islandwide venereal disease control service.

Routine antenatal blood testing, introduced by the WHO team in 1951, is now being continued at all antenatal clinics in Colombo as well as in a large number of antenatal clinics throughout the island. The laboratory services have been improved and serological tests for syphilis are being done in several provincial laboratories.

Courses on venereal diseases and their control are given to undergraduates, postgraduates, and paramedical personnel by the clinic staff at Colombo throughout the year.

The Port Venereal Disease Clinic, Colombo, was re-opened in 1958 on a daily basis. It serves both seafarers and dock-workers as well as others in the vicinity. Facilities for the diagnosis and treatment of venereal diseases are now also provided for at the other two ports of Ceylon.

Most of the particulars regarding the very early years of VD control in Ceylon have been collected from the annual Medical Administration Reports preserved at the Records Office of the Department of Health Services, Colombo.

We wish to thank Dr C. J. L. Misso and Mr D. T. S. S. Gunewardene for particulars regarding control measures taken at the VD Clinic, Colombo, during the early 1940s. Our thanks are also due to Mr Lyn Fonseka, Librarian of the Ceylon Museum Library, for references to ancient medical works in Ceylon and to Miss Wijesuriya, our stenographer, for assistance in typing. We are grateful to the Director of Health Services, Ceylon, for permission to publish this paper.

\section{REFERENCES}

De Silva, W. A. (1913). J. Ceylon Brch R. Asiat. Soc., 23, 34. Laird, S. M. (1952).WHO Int/VD/57, October 13, 1952. (1959). WHO Int/VDT/120, May 4, 1959.

Lees, R. (1961). Brit. J. vener. Dis., 37, 187.

Pereira, E. D. C. (1962). Ibid., 38, 90.

Pieris, P. E. (1909). "Ribeiro's History of Ceilão" (trans.), 2nd ed., p. 156, Colombo Apothecaries, Colombo.

Histoire du contrôle des maladies vénériennes à Ceylan

\section{RÉSUMÉ}

Les maladies vénériennes ont existé à Ceylan depuis le 5 ième siècle après Jésus-Christ. Cependant, ce n'est que depuis cent ans que des mesures ont été prises pour les contrôler. Des mesures systématiques de contrôle ont été introduites en 1921 et ont été améliorées au cours des années.

L'organisation de base des services de maladies vénériennes de Ceylan est due aux efforts du regretté Dr H. C. P. Gunewardene lorsque ce dernier revint à l'île de Ceylan en 1939, après avoir fait ses études à l'étranger. A cause du manque de personnel, ces services disparurent presque complètement aux environs de 1951 .

Entre 1949 et 1953 l'Organisation Mondiale de la Santé (OMS) apporta une aide considérable, ainsi qu'avis et encouragement en vue de réorganiser le contrôle des maladies vénériennes dans l'île.

L'examen serologique prénatal, introduit par l'équipe de l'OMS en 1951 est maintenant poursuivi dans tous les dispensaires prénataux, à Colombo ainsi que dans l'île entière. L'équipement des laboratoires a été amélioré et des examens sérologiques de la syphilis sont pratiqués dans plusieurs laboratoires provinciaux.

Pendant toute l'année, le personnel médical de Colombo donne des conférences aux étudiants, aux docteurs, et au personnel paramédical, sur les maladies vénériennes et leur contrôle.

Le dispensaire de maladies vénériennes du Port de Colombo fut réouvert en 1958, tous les jours. On y soigne les marins et dockers, de même que les malades des environs. Des facilités pour le diagnostic et le traitement des maladies vénériennes existent également dans les deux autres ports de Ceylan. 